\title{
Supporting English Language Learners in the Mathematics Classroom in the United States
}

\author{
Xiang Gong \\ Hang Gao \\ Princeton International School of Mathematics and Science, USA
}

Supporting English Language Learners (ELLs) has become a focused topic in mathematics education. This study reported on how ELL high-school students could be effectively supported to achieve their academic success in the mathematics classroom. It formulated the assessment rubrics of ELL's mathematics learning levels (MAT) and language development stages (ENG) at an international school. Data analysis showed there was a positive linear correlation between the MAT and ENG. In conjunction with further interviews, ELL students were classified and analyzed as two clusters and a group of four outliers. Possible strategies to support ELLs' mathematics success and language development were outlined.

Keywords: English language learner, mathematics learning level, language development stages, mathematics classroom.

Today's mathematics classroom includes students with diverse learning needs and interests, and this diversity is increasing as more English Language Learners (ELLs) enter the education system in the United States (U.S.). For all students, a large part of learning mathematics is learning the language of mathematics and using mathematics terminology meaningfully in academic and conversational settings. Unlike native speakers, ELLs differ from one another in their native languages, levels of English language development, and their prior learning and educational experiences. They may prefer learning modalities and styles (Asher, 1969), may be designated for special education training, need diverse teaching approaches (Lombardi, 2008), or they may have special interests in mathematics (Misty \& Qing, 2014).

Nowadays, more and more American schools, especially international schools are attracting bright, creative high school students from around the world. Therefore, it is challenging yet rewarding for math teachers to understand students' language development stages and mathematics learning levels to teach mathematics curriculum in ways that ensure all students, especially ELLs can understand the content and demonstrate what they have learned. 
This research focused on how ELL high-school students could be effectively supported to achieve their academic success in the mathematics classroom. For ELL students, this research sought how they might better adapt to the mathematics classroom; for teachers, it could provide them with effective strategies to support ELL students to achieve academic success. The research questions addressed were:

1. What is the relationship between mathematics and language?

2. How can math educators understand and measure ELLs' mathematics learning levels (MAT) and their language development stages (ENG)?

3. What is the relationship between ELLs' MAT and ENG?

4. How can math educators support ELLs' academic success in the mathematics classroom environment?

\section{Literature Review}

\section{Relationship between Mathematics and Language}

This literature review begins with a clarification of the relationship between mathematics and language, which has been studied resulting in diverse perspectives and based on different understandings about the role that language has on mathematics. Some researchers (Behrends, 2012; Peat, 1990; Usiskin, 1996; Wells, 2003) proposed that mathematics itself was a language. For example, Wells (2003) pointed out that the symbolic language of mathematics was an independent special-purpose language. It consisted of the symbolic expressions and statements used in calculation and presentation of results. Usiskin (1996) also presented several arguments for perceiving mathematics as a language; mathematics was constructed as a natural language with expressions that are sentence like. It had syntax and symbols that function as verbs, and learning mathematics was like learning a second language.

The second point of view perceived language as a useful tool to communicate mathematics. This perspective was revealed in research articles where mathematical language was referred to as simply the means to express mathematics. This view signaled a separation between language and mathematics. For example, Hickendoff (2013) indicated that students' language level had differential effects on two mathematical abilities, problem solving and computation, and effects were found to be greater on applied problem solving than on computational skills. Lim, Stallings, and Kim (2016) identified issues related to prioritizing academic language in teaching performance assessments. The researches proposed a pedagogical approach to middle-grade mathematics teacher candidates to develop lesson plans that connected objectives and language functions by identifying language functions as learning objectives in their lesson plans and ensuring the lesson segment involved the intentional use of vocabulary, syntax, or discourse, as well as facilitated learning to achieve the objectives. 
In summary, different perceptions between language and mathematics existed in the current literature. Some researches discussed language as mathematics itself or part of mathematics, while other works claimed mathematics was separate from language. In this paper, our discussion was based upon, but not limited to the second viewpoint. In order to consider the integration of language and mathematics, three commonly acknowledged points were stated as follows:

1. Mathematics is the study of topics such as quantity (numbers), structure, space, and change. Mathematics has its own language system because it requires more precision than everyday speech. Pieter (2016) referred to this precision of language and logic as "rigor".

2. In the learning environment at school, English language is the gatekeeper for access to higher level coursework in the mathematics classroom. Therefore, English proficiency plays a key role in mathematics success, especially for ELLs.

3. As Moschkovich (2015) stated, English language in mathematics classrooms ranged from the language of mathematics - a list of academic vocabulary or technical words with precise meanings, to communicative language necessary and sufficient for competent participation in mathematical discourse practices.

\section{English Proficiency and Math Achievement of English Language Learners}

In terms of ELLs' English proficiency and math achievement, many reports and articles in different countries and regions of the world have been written on the effects of language on mathematics achievement, which indicated the importance of language in achievement generally, including mathematics (Berry, 1985; Clarkson, 1991; Tartre \& Fennema, 1995). For instance, Howie and Plomp (2003) analyzed the performance of South African pupils on the Third International Mathematics and Science Study-Report (TIMSS-R), which showed that in South Africa, pupils tended to achieve higher scores in mathematics when their language proficiency in English was higher. Guglielmi (2012) developed a bilingual education theory, which posited that retention, and continued development of native language skills facilitated academic achievement through two mediating mechanisms. This model exhibited excellent fit only in the Hispanic portion of the ELL sample. Consistent with the broader literature, ethnicity appeared to serve as an important moderator of the way native language proficiency related to self-perception, and math and science achievement.

\section{Methods}

\section{Participants}

This research mainly reported on high school ELL students from a new international school in New Jersey, USA. The school had a STEM focus and 
was founded in 2013. The total number of the ELLs was 64, from which 40 students were selected by simple random sampling. Research team got an alphabetical roster from the math department and numbered the ELL students from 1 to 64 . Then a random number generator was used to choose 40 numbers from 1 to 64 . However, as 3 selected students did not want to participate in this research, there were only 37 participants including 9 freshmen ( $9^{\text {th }}$ grade), 12 sophomores $\left(10^{\text {th }}\right.$ grade $), 7$ juniors $\left(11^{\text {th }}\right.$ grade), and 9 seniors $\left(12^{\text {th }}\right.$ grade). Most of them were from China, 2 from Russia, 1 from Spain, and 1 from Belarus (see Table 1).

Table 1

Number Distribution of the ELL Students

\begin{tabular}{lcccc}
\hline & Grade 9 & Grade 10 & Grade 11 & Grade 12 \\
\hline Male & 6 & 10 & 5 & 8 \\
Female & 3 & 2 & 2 & 1 \\
Total & 9 & 12 & 7 & 9 \\
\hline
\end{tabular}

\section{Procedure}

It was worth noting that mathematics teachers in this international school had understood the student background and provided specialized instruction in the mathematics classroom to help their ELL students bring language and math learning together. Mathematics teachers learned about the importance of language acquisition, building background knowledge, increasing student language production, and explicitly teaching academic language. Despite improving the teachers' preparation for teaching ELL students, the results on student' math achievement remained limited. For example, according to the AP Instructional Planning Reports, the ELL students' AP statistics scores, which relied more on language, were relatively lower than those of AP calculus BC. In addition, the ELL students' average score of contextual questions was lower than that of non-contextual questions.

To help ELL students achieve more success in the mathematics classroom, a two-phase study was designed, and the results were reported in this section. Phase one of the study concentrated on the structure of ELL students' mathematics learning levels and language development stages. This process provided a framework to analyze students' mathematics and language performance. The second phase was an exploratory and analytical phase focusing on the data analysis related to the relationship of mathematics and English language achievement based on the first phase. The data analysis, in conjunction with student interviews, were included to investigate the factors affecting the ELLs' performance and to find the ways to further support their academic success.

\section{Data Collection}

In order to quantify and measure ELL students' mathematics and English performance, our initial thought was to review the 37 participants' 
cumulative mathematics grades and English grades from the previous school year. This method was relatively simple and straightforward. The mathematics scores, which were given on the basis of ELLs' year-round performance in the course, consisted of 4 parts with different weights (class participation 10\%, homework 30\%, quiz and test 30\%, and final exam 30\%). Similarly, the English scores were summarized by four dimensions of class participation (10\%), homework (20\%), coursework (30\%), and final project (40\%). However, during the process of data collection, we frequently found that the data we collected did not objectively and truly reflect the academic level of students. One of the reasons was that teachers' annual evaluation of the students was not completely uniform. We noticed that grading differences were significant for two groups of students who were taught by different teachers. Therefore, our research team decided to develop new standard-based rubrics to identify ELLs' academic performance in mathematics and English with more accuracy and comprehensiveness.

According to the new rubrics, ELL students would be scored according to their mathematics learning levels (MAT) and language development stages (ENG) in three steps. Firstly, a spreadsheet was created by the research team, listing each participant's name, grade, gender, and all the dimensions of MAT and ENG, which would be further explained in the instrument section of this paper. Secondly, three mathematics teachers and three English teachers were invited to work individually in a classroom during their office hour time to score independently based on the MAT and ENG rubrics. These scores were then collected and calculated separately according to the rubrics to get the overall score of each individual participant. Thirdly, three overall scores from three mathematics teachers were averaged to obtain the MAT score of each participant. The ENG scores were created in the same way. These scores, in total, were used to analyze the relationship between MAT and ENG.

\section{Instrument}

To formulate standard-based rubrics we mentioned in the previous part, we sought to understand students' mathematics learning levels. These levels would help us define how student work met today's standards, allowing us to distinguish among different mathematics levels of performance. We referred to mathematics standards, such as NCTM Principles and Standards for School Mathematics (2000) and the Common Core State Standards for Mathematics (CCSSM) (2010). We also focused our attention on several dimensions that reflected the students' mathematics learning levels. These dimensions were catalogued as understanding, reasoning, problem solving, and procedures. Then, we reviewed and referred to relevant researches regarding the relationship between language and mathematics standards. For instance, Moschkovich's work (2012) was helpful for his outlined recommendations for meeting the challenges in developing mathematics instruction for ELLs in alignment with the Common Core Standards. Winn, Choi, and Hand (2016) were also consulted 
for their examination of how terms within the CCSSM and the Next Generation Science Standards (NGSS) could be used. Finally, based on the above literature for ensuring a comprehensive data analysis, we refined the dimensions and put "communicating" as a separate dimension in order to emphasize the influence of ELL's language factors on mathematics learning.

\section{Table 2}

\begin{tabular}{|c|c|c|}
\hline $\begin{array}{l}\text { Level/ } \\
\text { Dimensions }\end{array}$ & $\begin{array}{l}\text { Score } \\
\text { Range }\end{array}$ & Understanding \& Reasoning (UR) \\
\hline Advanced & $7-9$ & $\begin{array}{l}\text { Students show deep understandings of mathematics } \\
\text { including the ability to identify the appropriate concepts } \\
\text { and the information necessary for solving math } \\
\text { questions. } \\
\text { Evidence is used to justify and support decision made } \\
\text { and conclusions reached. }\end{array}$ \\
\hline Intermediate & $4-6$ & $\begin{array}{l}\text { Students show broad understandings of mathematics and } \\
\text { understand major concepts and components necessary } \\
\text { for solving math questions. } \\
\text { A systematic approach and/or justification of correct } \\
\text { reasoning is present. }\end{array}$ \\
\hline Elementary & $1-3$ & $\begin{array}{l}\text { Students show some understandings of mathematics and } \\
\text { understand some, but not all of the concepts and } \\
\text { components necessary for solving math questions. } \\
\text { Some or no correct reasoning or justification for } \\
\text { reasoning is present with trial and error. }\end{array}$ \\
\hline
\end{tabular}

Table 3

Mathematics Learning Level Rubric - Problem-solving \& Procedures

\begin{tabular}{|c|c|c|}
\hline $\begin{array}{l}\text { Level/ } \\
\text { Dimensions }\end{array}$ & $\begin{array}{l}\text { Score } \\
\text { Range }\end{array}$ & Problem-solving \& Procedures (PP) \\
\hline Advanced & $7-9$ & $\begin{array}{l}\text { Students use creative, efficient strategies and complex } \\
\text { reasoning leading directly to a completed solution. } \\
\text { Applies procedures accurately to correctly solve the } \\
\text { problem and verify the results. }\end{array}$ \\
\hline Intermediate & $4-6$ & $\begin{array}{l}\text { Students use strategies that are partially useful, leading } \\
\text { some way towards a solution or part of a solution. } \\
\text { There is some evidence of mathematical reasoning. } \\
\text { Mathematical procedure used. }\end{array}$ \\
\hline Elementary & $1-3$ & $\begin{array}{l}\text { No evidence of a strategy that helps solve math } \\
\text { questions. } \\
\text { Some reasoning or justification for reasoning is present } \\
\text { with trail or error. } \\
\text { Could not completely carry out mathematical } \\
\text { procedures. }\end{array}$ \\
\hline
\end{tabular}


Table 4

\begin{tabular}{lcl}
\multicolumn{3}{c}{ Mathematics Learning Level Rubric - Communicating } \\
\hline $\begin{array}{l}\text { Level/ } \\
\text { Dimensions }\end{array}$ & $\begin{array}{l}\text { Score } \\
\text { Range }\end{array}$ & Communication $(\mathrm{COM})$ \\
\hline Advanced & $7-9$ & $\begin{array}{l}\text { Mathematical representation is actively used as a } \\
\text { means of communicating ideas related to the solutions } \\
\text { of the problem. } \\
\text { There is appropriate use of accurate mathematical } \\
\text { representation. } \\
\text { There is some use of appropriate mathematical } \\
\text { representation. }\end{array}$ \\
Elementary & $1-3$ &
\end{tabular}

According to the dimensions, students' scores of mathematics learning levels (MAT), would be assessed by an examination of understanding and reasoning (UR) (see Table 2), problem-solving and procedures (PP) (see Table $3)$ ", and "communication (COM) (see Table 4). The math department teachers completed the rubrics to minimize any possible bias. The mean values of three teachers' scores were collected to calculate the total score by the following weighted linear formula:

$$
M A T=U R \times 40 \%+P P \times 40 \%+C O M \times 20 \%
$$

To assess the students' English reading and writing proficiency, a regular placement test was held at the beginning of every school year. After reading a mathematics or science related article, the students would answer a few questions and then write a well-structured essay. In the essay, students were expected to clearly state their arguments and support them with evidence from the article. The scoring rubrics, which were formulated based on expectations of native speakers, which examined reading comprehension, syntax, diction, fluency, and analysis. Each criterion was put on a scale of 1 to 5 , with 1 as limited and 5 as mastery. Students would be placed into Advanced Class or Intermediate Class or placed out according to their unweighted final score.

To better reflect the ELL students' English proficiency, however, the scoring rubrics are needed to be modified for five considerations.

1. ELLs face different language problems from those of the native speakers. For instance, writing complex sentences with skillful use of particle phrase and subordinate clause may be a major obstacle for ELLs, but not for the native speakers, which is the same case with decomposing complex sentence structures in reading comprehension. Therefore, the scoring rubrics needed to take into account the linguistic challenges typical for a range of ELLs.

2. For ELLs, we needed to account for writing, reading, speaking and listening to comprehensively reflect the students' English level (see Table 5, Table 6, Table 7, and Table 8). Students not only read books or write papers, but also gave presentations and participated in classroom discussion. Their speaking and listening capabilities played an integral role in exchanging ideas 
and creating an active learning environment in class.

\section{Table 5}

Writing Rubrics and Weight (Writing 30\%)

\begin{tabular}{|c|c|c|}
\hline $\begin{array}{l}\text { Sub- } \\
\text { standards }\end{array}$ & $\begin{array}{l}\text { Score } \\
\text { Range }\end{array}$ & Description \\
\hline \multirow[t]{4}{*}{$\begin{array}{l}\text { Syntax } \\
40 \%\end{array}$} & 4 & $\begin{array}{l}\text { Varied sentence structure, skillful use of participle } \\
\text { phrase, subordinate clause, and diversified subject. }\end{array}$ \\
\hline & 3 & $\begin{array}{l}\text { Some variation in sentence structure, a couple of attempts } \\
\text { in using participle phrase, subordinate clause, and } \\
\text { diversified subject; some awkwardness in syntax. }\end{array}$ \\
\hline & 2 & $\begin{array}{l}\text { All basic sentence structures; word order needs attention } \\
\text { in some places. }\end{array}$ \\
\hline & 1 & $\begin{array}{l}\text { Not in complete sentences/fragments or run-ons; tortured } \\
\text { syntax }\end{array}$ \\
\hline \multirow[t]{4}{*}{$\begin{array}{l}\text { Fluency } \\
40 \%\end{array}$} & 4 & $\begin{array}{l}\text { Few grammar errors, incorrect diction choices, comma } \\
\text { splices, useless words or made-up patterns; some dead } \\
\text { words (2-3) }\end{array}$ \\
\hline & 3 & $\begin{array}{l}\text { Several glaring grammar errors, incorrect diction choices, } \\
\text { comma splices, useless words or made-up patterns; many } \\
\text { dead words (4-5) }\end{array}$ \\
\hline & 2 & $\begin{array}{l}\text { Many glaring grammar errors, incorrect diction choices, } \\
\text { comma splices, useless words or made-up patterns; more } \\
\text { than } 5 \text { dead words }\end{array}$ \\
\hline & 1 & $\begin{array}{l}\text { Errors in grammar, tense choice, plurals, gender } \\
\text { pronouns, or spelling interfere with an understanding of } \\
\text { the writer's meaning }\end{array}$ \\
\hline \multirow[t]{4}{*}{$\begin{array}{l}\text { Organizatio } \\
\mathrm{n} \\
20 \%\end{array}$} & 4 & $\begin{array}{l}\text { An effective hook and a working thesis statement; topic } \\
\text { sentences in each body paragraph; a concluding } \\
\text { paragraph that echoes the thesis }\end{array}$ \\
\hline & 3 & $\begin{array}{l}\text { A hook and a working thesis statement; topic sentence in } \\
\text { each body paragraph; a concluding paragraph that } \\
\text { summarizes the topics }\end{array}$ \\
\hline & 2 & $\begin{array}{l}\text { A weak thesis statement; no topic sentences; a conclusion } \\
\text { that echoes the thesis }\end{array}$ \\
\hline & 1 & $\begin{array}{l}\text { A weak thesis statement; no topic sentence; no } \\
\text { conclusion }\end{array}$ \\
\hline
\end{tabular}

3. Writing, reading, speaking and listening carry 30\%, 25\%, 25\% and 20\% of weight respectively. Writing needed to have the highest weight simply because it was used most frequently: quiz, essay, research paper, lab report, and college application etc.; the school offered a Writing Lab twice a week during club periods: one and a half hours on Wednesdays and Fridays. Listening needed to have a lower weight because the native speakers at school, whether teachers or students, tended to use simple words, repetition or paraphrases when talking with international students, which made 
listening more "ELL-friendly". As a result, we designed a formula to reflect the weighted dimensions as:

English Proficiency Score $=$ Writing $\times 30 \%+$ Reading $\times 25 \%+$ Speaking $\times 25 \%$

$$
+ \text { Listening } \times 20 \% \text {. }
$$

4. The writing assessment standards needed to carry different weights. For example, organization appeared much easier to master than syntax, because the golden format of "an intriguing hook, a working thesis, topic sentences, and a conclusion" could be learned faster; however, syntax consisting of numerous grammar concepts often daunt ELLs, especially those whose mother tongue differs a lot from English. Therefore, for the writing assessment, syntax needed to carry more weight than organization. The formula was:

Writing $=$ Syntax $\times 40 \%+$ Fluency $\times 40 \%+$ Organization $\times 20 \%$.

5. The speaking assessment standards also needed to carry a different weight. Specifically, delivery and language because they are equally important for a listener's pleasant experience; listener effort is low when the quality of delivery and language use is high. The formula needed to reflect these important considerations as:

$$
\text { Speaking }=\text { Delivery } \times 50 \%+\text { Language } \times 50 \% \text {. }
$$

Integrating the existing rubrics, which previously only focused on reading and writing, with the practice of teaching ELL students, and English Proficiency Standards Framework we formulated a new approach to comprehensively reflect the ELL students' English language competency in the classroom.

Table 6

Reading Rubrics and Weight (Reading 25\%)

\begin{tabular}{cl}
\hline $\begin{array}{l}\text { Score } \\
\text { Range }\end{array}$ & Description \\
\hline 4 & $\begin{array}{l}\text { Skilled at decomposing complex sentences; able to find the main idea, } \\
\text { important facts, and supporting details; capable of reading between the }\end{array}$ \\
& $\begin{array}{l}\text { lines by inquiring about the author's tone, intention, or main audience. } \\
\text { Minor difficulty in decomposing complex sentences; able to grasp the } \\
\text { main idea but may lose track of a few important facts or supporting } \\
\text { details; generally understand the author's tone, intention, or main } \\
\text { audience } \\
\text { Major difficulty in decomposing complex sentences, as well as } \\
\text { understanding the main idea, important facts or supporting details; } \\
\text { hardly understands the author's tone, intention or main audience } \\
\text { Unable to decompose complex sentences; significant difficulty in } \\
\text { understanding the main idea; no clue about the author's writing } \\
\text { purpose }\end{array}$ \\
&
\end{tabular}


Table 7

Speaking Rubrics and Weight (Speaking 25\%)

\begin{tabular}{lcl}
\hline $\begin{array}{l}\text { Sub- } \\
\text { standards }\end{array}$ & $\begin{array}{c}\text { Score } \\
\text { Range }\end{array}$ & Description \\
\hline $\begin{array}{l}\text { Delivery } \\
50 \%\end{array}$ & 4 & $\begin{array}{l}\text { Generally fluid speech, good command of pronunciation } \\
\text { and intonation } \\
\text { Minor difficulty with speech fluidity, pronunciation and } \\
\text { intonation }\end{array}$ \\
& 2 & $\begin{array}{l}\text { Some difficulty with speech fluidity, but pronunciation and } \\
\text { intonation may affect intelligibility } \\
\text { Major challenge in speech fluidity, pronunciation and } \\
\text { intonation. Significant listener effort is needed }\end{array}$ \\
Use & 4 & $\begin{array}{l}\text { Few grammar or diction errors. A good combination of } \\
\text { simple and complex sentence structures. Good command of } \\
\text { idiomatic expressions. }\end{array}$ \\
$50 \%$ & 3 & $\begin{array}{l}\text { Occasional grammar errors, diction misuse and made up } \\
\text { expressions. Mostly simply sentence structures. } \\
\text { Intelligibility is generally good. }\end{array}$ \\
& 2 & $\begin{array}{l}\text { Frequent grammar errors, diction misuse and made up } \\
\text { expression. Significant listener effort is needed. } \\
\text { Frequent grammar errors. Speech is full of basic diction, } \\
\text { expressions and sentence structures. The student is unable } \\
\text { to express complex meanings. }\end{array}$ \\
\hline
\end{tabular}

Table 8

Listening Rubrics and Weight (Listening $20 \%$ )

Score Description

Range

$4 \quad$ Students are able to grasp the main idea and important details in daily conversation, news report, or movies etc. They have a large vocabulary and hardly need paraphrase or repetition. They are good at contextualizing unfamiliar words or expressions.

3 Students have minor difficulty understanding the main idea or important details in daily conversation, news report, or movies etc. They might need paraphrase or repetition occasionally. They know how to contextualize unfamiliar words or expressions.

2 Students have major difficulty understanding the main idea or important details in daily conversation, news report, or movies etc. They need paraphrase or repetition frequently. They have major challenge contextualizing unfamiliar words or expressions.

1 Students have major challenge understanding the listening material or the teachers. They have to read the transcripts or frequently need paraphrase or repetition.

\section{Data Analysis}

After the data from 37 participants were collected, the IBM SPSS 18 package was used to process the relationship between two variables of 
participants' MAT and ENG. As both MAT and ENG were quantitative variables, a Pearson correlation coefficient was calculated. In addition, a scatter plot showed that most of the data fell into two primary clusters (16 students in Cluster 1 and 17 in Cluster 2) except for 4 outliers. Therefore, a three-round face-to-face interview was conducted in the mathematics office to explore further information from participants in three different cohorts respectively. The research team randomly selected 6 interviewees, each two per cluster from the scatter plot, as well as 2 outliers. Before the interview, all 6 interviewees were given informed consent. Research team told them the nature and purpose of this research study and any possible discomfort it might bring. With all interviewees consented in writing, each round of the interview started with 2 interviewees explaining how their English level affected their mathematics performance, then followed by the research team asking the interviewees some additional questions. Within 30 minutes of each round, the interviewees were expected to provide detailed examples to support their ideas. With permission by students prior to the interviews, their voices were recorded for the research. After each session, a summarized interview review was written by the interviewer, and then sent to the interviewees to obtain feedback. The findings of the data analysis and interviews are showed below.

\section{Results}

\section{Findings from the Data Analysis}

Shown from Table 9, the descriptive statistics of MAT indicated that the mean value was $M=7.2270$, and the standard deviation was $S D=0.79325$. The lower quartile of MAT was $Q_{1}=6.8000$, and the upper quartile $Q_{3}=7.6000$. The mean value of ENG was $M=3.2705$, with its standard deviation $S D=$ 0.48133 . The lower quartile of ENG was $Q_{1}=2.9400$, and the upper quartile $Q_{3}=3.7500$. Linearity test showed there was a moderate linear relationship between MAT and ENG (see Figure 1). The Q-Q plot indicated that both MAT and ENG roughly followed the normal distribution (see Figure 2).

Table 9

Descriptive Statistics of MAT and ENG

\begin{tabular}{llll}
\hline & & MAT & ENG \\
\hline $\mathrm{N}$ & Valid & 37 & 37 \\
& Missing & 0 & 0 \\
Mean & & 7.227 & 3.2705 \\
Std. Deviation & 0.7932 & 0.48133 \\
Minimum & 5 & \\
Maximum & 5.6 & 2 \\
\hline
\end{tabular}




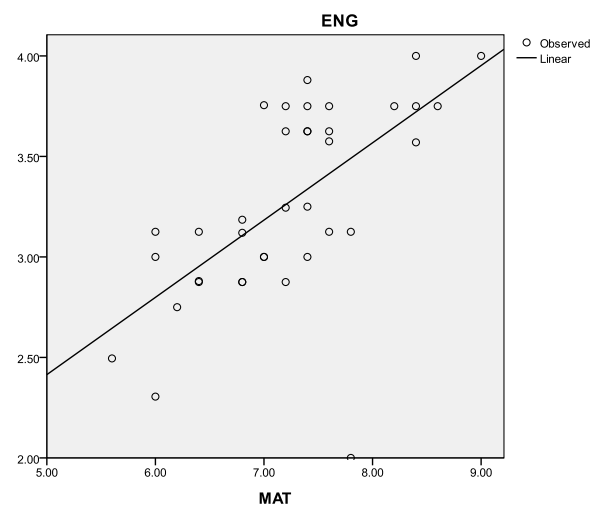

Figure 1. Linearity Test between MAT and ENG
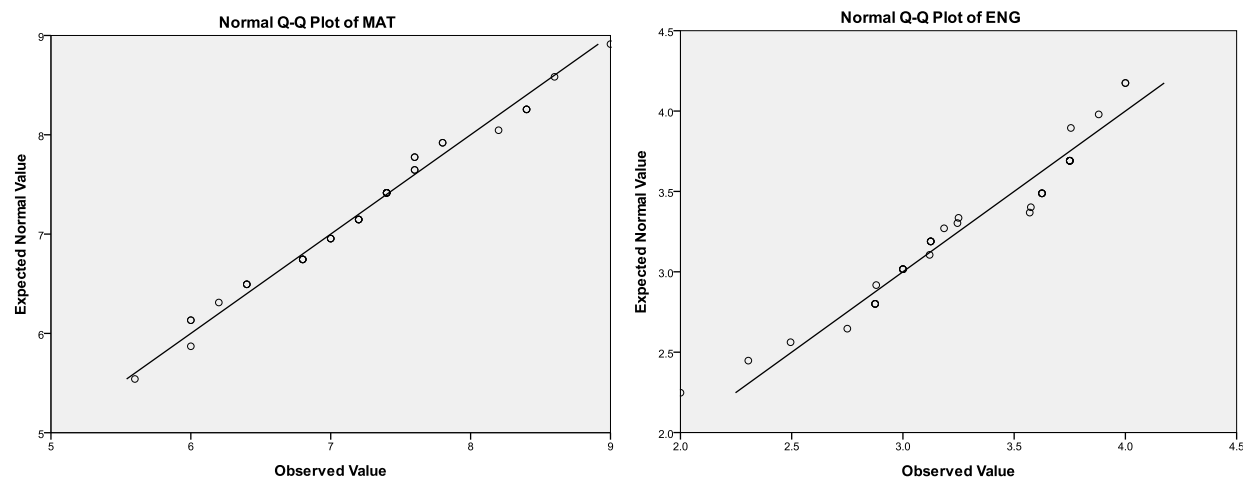

Figure 2. $Q-Q$ Plots of MAT and $E N G$.

Pearson's correlation coefficient showed that there was positive linear correlation between MAT and ENG (see Table 10). The correlation coefficient $r=0.634$, which was significant at the 0.01 level $(p=0.01)$.

\section{Table 10}

\begin{tabular}{llll}
\multicolumn{4}{c}{ Correlation between MAT and ENG } \\
\hline & & ENG & MAT \\
\hline ENG & Pearson Correlation & 1 & $.634^{* *}$ \\
& Sig. (2-tailed) & & .000 \\
& N & 37 & 37 \\
MAT & Pearson Correlation & $.634^{* *}$ & 1 \\
& Sig. (2-tailed) & .000 & 37 \\
& $\mathrm{~N}$ & 37 & \multicolumn{3}{c}{37} \\
\hline$* *$. & Correlation is significant at the 0.01 level (2-tailed).
\end{tabular}

From Figure 3 we could see that generally there were 2 clusters of students in the scatter plot. The red oval circled the Cluster 1 students, whose mathematics level and English proficiency were higher than the Cluster 2 students circled by a blue oval. Besides, there were 4 outliers isolated from two 
cluster.

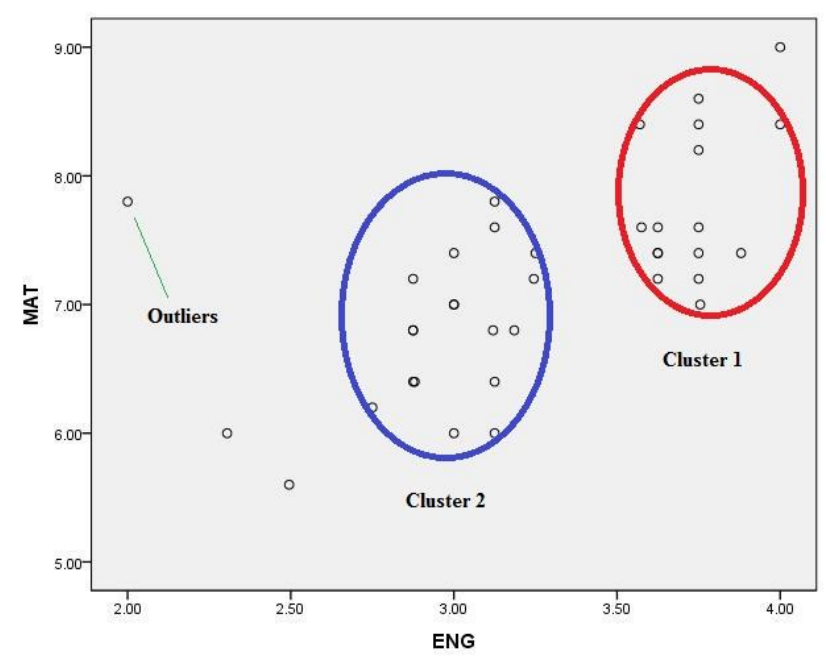

Figure 3. Scatter Plot of MAT and ENG

\section{Interview Findings}

Cluster 1 students. Interviews with students from Cluster 1 showed that students' excellence in mathematics could be primarily explained by two reasons. On the one hand, these students either learned some high-school level mathematics by themselves or were taught by teachers when they were in middle school. On the other hand, the mathematics curriculum standards at middle school level in the United States were relatively easier than those in their own countries. Thus, most of the ELL students had already met or partially met the $9^{\text {th }}$ or $10^{\text {th }}$ grade mathematics course standards when they entered this international school. Nine students were even capable of skipping the fundamental mathematics course (Geometry 1 or Algebra 2) and directly leaped to the advanced level course (Pre-calculus or calculus). Interviewees also mentioned that the school provided them with sufficient mathematics courses and flexible course options at different levels, which gave them more flexibility to make decisions.

However, just as every coin has two sides, this also brought some new challenges to ELL students, as their mastery of prior knowledge might cover the lack of language proficiency in mathematics courses. In the daily teaching and learning practice, math teachers found that ELLs felt more comfortable to solve problems, which needed prior knowledge, or to answer questions simply with numbers, symbols and graphs, rather than any complicated contextual description or situation. When asked to explain their problem-solving strategies, ELLs were more likely to write down the answer in steps, instead of narrating the whole process in words.

As time went by, when students started to learn new mathematics knowledge that they never learned before, they had to face the challenges as 
they had neither been exposed enough to such intensive practice of difficult questions, nor fully prepared to learn new mathematics knowledge in a foreign language. Of course, the improvement of their English language capability might alleviate some of the challenges, but eventually, they would need to go through an adaptation period.

In summary, for students in Cluster 1, we found that the influence of language factors on their math learning level would not appear immediately. Instead, the latency would last for a period of time (usually one semester or two). After the latency period, English proficiency started to influence the ELL students' mathematics performance explicitly.

Cluster 2 students. From Figure 3 we noticed that there was some overlap between Cluster 1 and 2 students in terms of math level; however, Cluster 2 students were still lagging behind Cluster 1 students as a whole. Therefore, we took interviews with two representatives from Cluster 2. Both of them felt they were not very good at mathematics. One interviewee said he was more interested in engineering. The other student showed a strong desire to learn mathematics well, but she admitted she still had potential to be better.

Interviewees argued that sometimes they had difficulty recognizing and retaining math concepts and generalizations. With the math difficulty increasing, mathematical concepts became more and more abstract, which made them feel overwhelmed. Thus, they had to learn mathematics in a way that relied heavily on rote memorization isolated from meaning. This method could temporarily solve some easy mathematical problems, but it could not bring any benefit to in-depth understanding.

When it came to the influence of language, students held the opinion that unlike native speakers, they encountered difficulties in understanding the mathematics content from the second language. They felt anxious when they were asked to express their understanding about the content when delivering a presentation or organizing an in-class group discussion. This would wear down their confidence and make them fall below the expected level of mathematics achievement in their class. Therefore, it was expected for math teachers to create a safe and communication-friendly classroom to make them feel more comfortable to experiment with their language to learn more content.

Other students. Other students, who were outside the two ovals, could be roughly classified as outliers. In fact, those students needed special care and help from teachers in the mathematics classroom. We discuss more strategies to help this group of students in the next part of the paper.

\section{Discussion}

\section{Creating a Safe and Inclusive Classroom Environment}

Our findings in this research indicated that ELL students' English language skills impacted their math learning and performance, which confirmed the effects of language on mathematics achievement (Berry, 1985; Clarkson, 
1991; Tartre \& Fennema, 1995). In addition, the positive correlation between MAT and ENG verified Howie and Plomp (2003)'s research results. Furthermore, our findings revealed the influence of anxiety on ELL students' mathematics achievement and the necessity to develop a strong sense of classroom community that encouraged positive interactions and cooperative learning.

To clarify the influence of anxiety on students, some researchers (DelliCarpini, 2009; Martirossian \& Hartoonian, 2015) found that due to xenoglossophobia, known as foreign language anxiety, people felt uneasy and nervous when using a foreign language. Other researchers (Abedi, Lord, Hofstetter, \& Baker, 2000; Beth, 2016) indicated that with ELLs' anxiety lowered, they were physiologically more able to accept new challenges and grapple with new concepts and problems. Therefore, math teachers are expected to create a safe and inclusive classroom environment to lower ELL students' anxiety. Relevant researches indicated that ELLs' English capability would improve swiftly by participating in well-designed discussions and activities (Pennock-Roman \& Rivera, 2011). So effective approaches can be made by math teachers to make ELLs feel at ease as a member of the class, such as designing meaningful in-class activities, organizing group discussions and presentations, and scaffolding research-based projects. In this environment, ELL students will naturally respect each other's ideas, be patient with one another, recognize there can be multiple perspectives and ways of learning, and highlight the value of individual contributions to group learning. Meanwhile, their math teachers can better recognize their current level of knowledge and facilitate their academic growth as a self-directed learner.

\section{Changing Classroom Discourse}

Based on our previous findings, the ELLs cannot be left to stay in their comfort zone to repeat learning the prior knowledge and disregard the language improvement. Instead, they should be provided with more challenges in class, which will push them to express their ideas of the problem-solving procedures, and to think and learn new mathematics content in a foreign language. Researches show that if teachers can actively engage their students in classroom discourse, they are likely to engage them in more meaningful and sustained learning experience (Blanton, Berenson, \& Norwood, 2001; Walshaw \& Anthony, 2008). Therefore, it is important to change students' classroom experiences into meaningful ones that develop their interests by changing the prominent routines of classroom interactions and discourse. Productive classroom discourse is a key aspect for ELLs' development of mathematics level and language proficiency.

However, in practice, the class atmosphere is likely to be tense when we pilot a new discourse, because most ELL students, especially students similar to the Cluster 2 student, tend to keep quiet and be reluctant to speak out - their lack of confidence in both mathematics and language dampen their enthusiasm 
and motivation. To make more students get involved and transfer the classroom discourse into a student-engaged one, math teachers can apply more strategies to encourage their students. For example, one effective strategy is to ask students "yes" or "no" questions to bridge their language gaps at the beginning of the course (Shomoossi, 2004; Xie, 2007). If a student cannot express his/her mathematics ideas with complete sentences, teachers can always alert the student to new mathematical vocabulary in class before the concepts are taught, then write the key words on the whiteboard, ask follow-up questions, and paraphrase the comments for everyone to ponder. As their language skills improve, more difficult questions could be asked with "what" or "why". A combination of initiating and probing questions can also be an effective approach to further bring out students' ideas.

\section{Exposing Students to More Contextual / Real-life Problems}

It is worth noting that based on the current evaluation system, although teachers are aware of the distinctions between ELLs and non-ELLs, it is still difficult to find out the significant differences between their mathematics grade levels. The advantages of ELL students (usually the Cluster 1 students) in mathematics will be cancelled out by their language weaknesses. Therefore, the final difference will not be significant compared with the non-ELL group.

However, research studies found that the performance gap between ELLs and non-ELLs was larger on linguistically complex items than on noncomplex items, regardless of the item content difficulty (Abedi \& Hejri 2004; Olson \& Goldstein, 1997). Word problems or contextual problems that typically have a mathematics structure in a more or less realistic problem situation, serve a central role for international reform of mathematics education (Abedi et al., 2000). Therefore, in their daily classroom practice, teachers should consider assigning students more contextual format questions than calculation questions if the learning conditions permit.

Another strategy is to link mathematical concepts to appropriate reallife contexts by using materials or problems. For instance, teachers highlight the modeling-oriented tasks in math classroom. This will support improvement with both language and reasoning skills (Sokolowski, 2015). This year, one of the teaching targets in the AP statistics class at the international school is to present topics numerically, geometrically, symbolically, and verbally, as students learn to communicate the connections among these representations. The justifications for the responses and solutions should also be part of the routine when solving problems. Students should also be encouraged to express their ideas in carefully written sentences that validate their process and conclusions.

\section{Applying Differentiated Pedagogy in the Mathematics Classroom}

In the traditional mathematics classroom, teachers instruct all students in the same subjects and in the same way. Teachers in the differentiated 
classroom, however, strive to base instruction on student interests, needs, and readiness and use various teaching processes and instructional approaches to ensure that students reach their potential (Abbati, 2012; Strassman, 2004; Wu $\&$ Chang, 2014). Shim and Shur (2017) pointed out that teachers not only needed to find the distinctions between ELLs and non-ELLs, but also realize ELL students' performance was on a spectrum, showing significantly different performance levels among groups or clusters. In particular, for the students who have special needs, one of the strategies is to form groups of students and to provide task differentiation within the various group participants. Teachers should understand that students who might be outliers might have unknown special talents in mathematics. Teachers can work with the English department in their school settings to establish language goal for each individual outlier student. Math teachers and English teachers can also cooperate to monitor the students work and to provide feedback based on students' individual learning goals.

\section{Conclusion}

This study aimed to examine how to support diverse learners, particularly ELLs to achieve academic success in the mathematics classroom. By clarifying the relationship between mathematics and language, as well as English language proficiency and math achievement of ELLs, this research utilized an evaluation framework for ELL students' mathematics learning levels and language development stages at the international school. Correlation coefficient analysis showed two factors were positively correlated. Based on the framework, ELL students were classified into two primary clusters. Drawing upon the quantitative analysis and interview data, we outlined strategies to support ELLs' mathematics success and language development, such as creating a safe and inclusive classroom environment, changing the classroom discourse, exposing students to more contextual / real-life problems, and applying differentiated pedagogy in the mathematics Classroom.

This study also suggests opportunities for future research. First, given that this research is based on the frameworks for ELL students' mathematics learning levels and English language proficiency, we noticed that there is a dearth of research on providing two-variable models or relevant evaluation scales for this topic. Second, future research might investigate possible differences in students' grade levels from 9th grade to 12th grade. Last but not least, this study provided a case study of ELL students' performance from a single international school. More researches can be conducted to determine if the correlation between ELL's mathematics and language capability is strongly positive on a larger scale - if the findings are representative of schools across other regions or countries. 


\section{References}

Abbati, D. G. (2012). Differentiated instruction: Understanding the personal factors and organizational conditions that facilitate differentiated instruction in elementary mathematics classrooms. UC Berkeley: Educational Leadership. Retrieved from: http://www.escholarship.org/uc/item/4kr1559n

Abedi, J., \& Hejri. F. (2004). Accommodations for students with limited English proficiency in the National Assessment of Education Progress. Applied Measurement in Education, 17(4), 371-392.

Abedi, J., Lord, C., Hofstetter, C., \& Baker, E. (2000). Impact of accommodation strategies on English language learners' test performance. Educational Measurement: Issues and Practice, 19(3), $16-26$.

Asher, J. (1969). The total physical response approach to second language learning. The Modern Language Journal, 53 (1), 3-17.

Berry, J. W. (1985). Learning mathematics in a secondary language: Some cross-cultural issues. For the Learning of Mathematics, 5(2), 18-23.

Beth, C. (2016). Classroom assessment and English language learners: Teachers' accommodations implementation on routine math and science tests. Teaching and Teacher Education, 54, 139-148.

Blanton, M., Berenson, B., \& Norwood, K. (2001). Using classroom discourse to understand a prospective mathematics teacher's developing practice. Teaching and Teacher Education, 17(2), 227-242.

Clarkson, P. C. (1991). Bilingualism and mathematics learning. Australia, Geelong: Deakin University.

DelliCarpini, M. (2009). Success with ELLs: Authentic assessment for ELLs in the ELA classroom. The English Journal, 98(5), 116-119.

Ehrhard, B. (2012). Mathema--Is mathematics the language of nature. (pp. 8799). In: Behrends E., Crato N., Rodrigues J. (Eds.), Raising public awareness of mathematics. Berlin, Heidelberg: Springer,

Howie, S. J., \& Tjeerd, P. (2003). Language proficiency and contextual factors influencing secondary students' performance in mathematics in South Africa. Paper presented at the annual meeting of the American Education Research Association, Chicago, IL.

Lim, W., Stallings, L., \& Kim, D. J. (2016). A proposed pedagogical approach for preparing teacher candidates to incorporate academic language in mathematics classrooms. International Education Studies, 8(7), 1-10.

Lombardi, J. (2008). Beyond learning styles: Brain-based research and English language learners. Clearing House, 81(5), 219-222.

Hickendoff, M. (2013). The language factor in elementary mathematics assessments: Computational skills and applied problem solving in a multidimensional IRT framework. Applied Measurement in Education. 26(4), 253-278. 
Martirossian, A., \& Hartoonian, A. (2015). Lowering foreign language anxiety through self-regulated learning strategy use. English Language Teaching, 8(12), 209-222.

Misty, A., \& Qing, Y. (2014). Language, mathematics and English language learners. Australian Mathematics Teacher, 70(3), 3-13.

Moschkovich, J. (2012). Mathematics, the common core, and language: Recommendations for mathematics instruction for ELs aligned with the common core. Retrieved from

http://ell.stanford.edu/sites/default/files/pdf/academic-papers/02-

JMoschkovich\%20Math\%20FINAL_bound\%20with\%20appendix.pdf

Moschkovich, J. (2015). Academic literacy in mathematics for English learners. Journal of Mathematical Behavior, 40, 43-62

Olson, J. E., \& Goldstein, A. A. (1997). The inclusion of students with disabilities and limited English proficiency students in large-scale assessments: A summary of recent progress. (NCES No. 97-482). Washington, DC: U.S. Department of Education, National Center for Education Statistics.

Peat, F. D. (1990). Mathematics and the language of nature. Retrieved from http://www.fdavidpeat.com/bibliography/essays/maths.htm

Pennock-Roman, M., \& Rivera, C. (2011). Mean effects of test accommodations for ELLs and non- ELLs: A meta-analysis of experimental studies. Educational Measurement: Issues and Practice, $30(3), 10-28$.

Pieter, V. J. (2016). Making a case for exact language as an aspect of rigour in initial teacher education mathematics programmes. Perspectives in Education, 34, 150-166.

Shomoossi, N. (2004). The effect of teachers' questioning behavior on EFL classroom introduction: A classroom research study. The Reading Matrix, 4(2), 24-46.

Shim, J. M., \& Shur, A. M. (2017). Learning from ELLs' perspectives: Mismatch between ELL and teacher perspectives on ELL learning experiences. English Language Teaching, 11(1), 21-32.

Sokolowski, A. (2015). The effect of math modeling on student's emerging understanding. IAFOR Journal of Education, 3(2), 142-156.

Strassman, B. K. (2004). Differentiated instruction in the English classroom: Content, process, product and assessment. Journal of Adolescent \& Adult Literacy, 48(4), 358.

Tartre, L. A., \& Fennema, E. (1995). Mathematics achievement and gender: A longitudinal study of selected cognitive and affective variables (grades 6-12). Educational Studies in Mathematics, 28, 199-227.

Usiskin, Z. (1996). Mathematics as a language. In P. C. Elliott (Ed.). Communications in mathematics, $K-12$ and beyond (pp. 231-43). Reston, VA: National Council of Teachers of Mathematics.

Walshaw, M., \& Anthony, G. (2008). The teacher's role in classroom discourse: 
A review of recent research into mathematics classrooms. Review of Educational Research, 78(3), 516-551.

Wells, C. (2003). A handbook of mathematical discourse. Case Western Reserve University. Retrieved from https://case.edu/artsci/math/wells/pub/pdf/paperhbk.pdf

Winn, K. M., Choi, K. M., \& Hand, B. (2016). Cognitive language and content standards: Language inventory of the common core state standards in mathematics and the next generation science standards. International Journal of Education in Mathematics, Science and Technology, 4(4), 313-339.

Wu, S., \& Chang, Y. (2014). Advancing kindergarten teachers' knowledge and capabilities of differentiated instruction associated with implementation of thematic integrated curriculum. Social and Behavioral Sciences, 177, 246-250.

Xie, C. M. (2007). A study of teacher questioning in interactive English classroom. Sino-US English Teaching, 4 (4), 29-37.

\section{Authors:}

Xiang Gong

Princeton International School of Mathematics and Science

19 Lambert Dr, Princeton NJ 08540, USA

Email:xiang.gong@prismsus.org

Hang Gao

Princeton International School of Mathematics and Science

19 Lambert Dr, Princeton NJ 08540, USA

Email: tiger.gao@prismsus.org 